\title{
RESSIGNIFICAÇÃO DOS PAPÉIS DE PROFESSORES E ALUNOS NA RELAÇÃO ENTRE PROJETOS DE ENSINO- APRENDIZAGEM E TECNOLOGIAS DIGITAIS DE REDE
}

\author{
Vitor Malaggi* \\ Karina Marcon ${ }^{* *}$ \\ Adriano Canabarro Teixeira ${ }^{* * *}$
}

\section{Resumo}

O presente artigo tem como objetivo principal discutir as relações e papéis de professores e alunos ressignificados em um contexto educativo de apropriação dos Projetos de EnsinoAprendizagem (PEAs) e das Tecnologias Digitais de Rede (TDRs). Neste sentido, inicialmente realiza-se uma revisão teórica sobre a utilização de Projetos na Educação enquanto sistema didático, bem como as possibilidades de imbricação das tecnologias desveladas no contexto social da cibercultura com os processos educativos. Por meio destas reflexões, torna-se possível embasar a análise e interpretação de um processo de pesquisa empírica, com caráter exploratório, realizado na E. E. E. F. Capistrano de Abreu, SoledadeRS. Com base nos resultados deste processo investigatório, o qual proveu um conjunto de dados que subsidiaram a discussão sobre PEAs e TDRs, estabeleceram-se conexões e relações que possibilitaram a proposição de novas explicações e interpretações para a problemática dos papéis de professores e alunos neste contexto.

Palavras-chave: Relações e papéis de professores e alunos. Tecnologias Digitais de Rede. Projetos de Ensino-Aprendizagem.

\section{REFRAMING TEACHERS AND STUDENTS' ROLES IN THE RELATIONSHIP BETWEEN TEACHING AND LEARNING PROJECTS AND NETWORKED DIGITAL TECHNOLOGIES}

\section{Abstract}

This paper's main objective is to discuss the relationships and roles of teachers and students in an educational context to adapt the Teaching and Learning Projects (PEAs) and Networked Digital Technologies (TDRs). To that end, it was initially carried out a theoretical review on the use of projects in educational system, as well as

\footnotetext{
* Mestre em Educação pela Universidade de Passo Fundo. E-mail: malaggi@gmail.com

** Doutoranda em Educação pela Universidade Federal do Rio Grande do Sul. E-mail: kamarcon@gmail.com

*** Doutor em Informática na Educação pela Universidade Federal do Rio Grande do Sul. Professor da Universidade de Passo Fundo. E-mail: teixeira@upf.br
} 
the possibility of introducing new technologies and cyberculture to teaching-learning processes. Based on these reflections, it is possible to acquire basis for analyzing and interpreting exploratory data in the empirical research held at E. E. E. F. Capistrano de Abreu, Soledade, RS. Based on the results of this investigative process, which provided a set of data supporting the discussion about PEAs TDRs, connections and relationships that enabled new explanations and interpretations to the problem of teachers and students' roles in this context were established.

Keywords: Teachers and students’ roles and relationships. Networked Digital Technologies. Teaching and Learning Projects.

\section{Introdução}

Neste artigo pretende-se demonstrar que a escola não deve ignorar os debates sobre a configuração sociocultural contemporânea, condicionada pelas reflexões acerca da cibercultura. Assim, tem-se como objetivo dissertar sobre quais seriam as possibilidades na apropriação educacional das TDRs e de suas características - entendidas como os artefatos tecnológicos nascidos da convergência da informática com as telecomunicações no seio da sociedade contemporânea - na potencialização dos pressupostos pedagógicos de um sistema didático por PEAs.

Para tanto, julga-se que pela apropriação educacional destas tecnologias seja possível proporcionar, por meio de processos de ensino-aprendizagem realizados por PEAs, uma relação entre professores, alunos e demais seres sociais/instituições pautada na apropriação coparticipada de conhecimentos. Ainda, acredita-se que os papéis e funções de professores e alunos devem ser reconfigurados neste contexto, confluindo para a possibilidade da constituição de relações entre os envolvidos nos processos educativos por meio de redes de ensino-aprendizagem. Por fim, a apropriação educativa das TDRs em conjunto com os PEAs torna possível abrir caminhos diferenciados para que novos espaços e tempos de aprendizagem sejam construídos, utilizando-se para isso do ciberespaço como ambiente virtual de comunicação e de interação social.

De maneira específica, as reflexões aqui propostas são focadas para uma categoria de análise extraída do contexto maior destas problemáticas: a ressignificação dos papéis de alunos e professores nos processos educativos pautados nos PEAs, os quais resultam potencializados pela a incorporação de características das TDRs.

Por meio da discussão teórica sobre o tema, unida com a análise de um conjunto de dados providos por uma investigação empírica realizada em uma escola de ensino fundamental pública, torna-se possível verificar que conceitos como interatividade, lógica das 
redes e hipermídia - os quais constituem as TDRs - podem ser apropriados nos processos educativos via PEAs, com vistas à constituição de relações diferenciadas entre professores e alunos. Nestes termos, tais relações serão embasadas na necessária coparticipação na apropriação dos conhecimentos, na ruptura com uma lógica vertical e hierárquica na práxis educativa e na conformação do papel do professor baseado na intervenção pedagógica que leve em conta o diálogo e a mobilidade dos centros, bem como do papel do aluno considerado em sua atividade e protagonismo, sem, contudo, deixá-lo cair no puro espontaneísmo.

\section{Estudo sobre as tecnologias digitais de rede}

O debate em torno das modalidades tecnológicas que possibilitam aos sujeitos da sociedade contemporânea processos de interação social e autoria colaborativa deve ser inicialmente pautado por um conjunto de reflexões acerca da nítida inter-relação entre sociedade, cultura e os seus artefatos tecnológicos. Neste contexto, tem-se a emergência de uma série de conceitos interligados que, em sua totalidade, permitem vislumbrar e compreender os fenômenos sociotécnicos, comunicativos e culturais contemporâneos.

Inicialmente, é importante pontuar as reflexões elaboradas por Lemos (2003) sobre a cibercultura, as quais tomam por base as análises iniciadas por Lévy (1999). A definição deste conceito é expressa por Lemos (2003, p. 11) da seguinte forma: a cibercultura caracteriza “[...] a forma sociocultural que emerge da relação simbiótica entre a sociedade, a cultura e as novas tecnologias de base micro-eletrônica que surgiram com a convergência das telecomunicações com a informática, na década de 70”. Com base nesta conceitualização, Lemos aprofunda sua análise por meio das denominadas "Leis da Cibercultura”.

A primeira lei, ou "Lei da Reconfiguração”, alerta que é preciso “[...] evitar a lógica da substituição ou do aniquilamento. Em várias expressões da cibercultura reconfiguram-se práticas, modalidades midiáticas, espaços, sem a substituição de seus respectivos antecedentes”. (LEMOS, 2003, p. 22). Já a segunda lei, denominada de “Lei da Liberação dos Polos de Emissão”, postula que as “[...] diversas manifestações sócio-culturais contemporâneas mostram que o que está em jogo com o excesso de informação nada mais é do que a emergência de vozes e discursos anteriormente reprimidos pela edição da informação pelos mass media”. (LEMOS, 2003, p. 23). Por fim, a terceira lei, a "Lei da Conectividade Generalizada”, começa segundo Lemos (2003, p. 23) “[...] com a transformação do PC em 
CC, e desse em CC móvel ${ }^{1}$. As diversas redes sócio-técnicas contemporâneas mostram que é possível estar só sem estar isolado”.

Para realizar uma compreensão mais aprofundada acerca da cibercultura e da dinâmica dos processos comunicacionais e sociotécnicos que se instauram em sua gênese, faz-se necessário entender os conceitos de hipertexto e de rede. Para Lévy (1993, p. 25) o hipertexto é “[...] uma metáfora válida para todas as esferas da realidade em que significações estejam em jogo".

Ao ser apropriada na esfera técnica do contexto da cibercultura, a metáfora do hipertexto pode ser compreendida como “[...] a apresentação de informações através de uma rede de nós interconectados por links que pode ser navegada livremente pelo leitor de um modo não-linear”. (RAMAL, 2002, p. 87). Ao “navegar” na estrutura de um hipertexto tornase possível verificar que os links efetuam ligações por meio de alguma expressão, frases ou palavras que remetem o leitor a outros fragmentos de informações. Estes fragmentos, por sua vez, podem possuir outros tantos links que compõem assim uma malha informacional que pode ser acessada de diversas formas e em diversas direções, dependendo para isso da própria intencionalidade do leitor, dos seus propósitos. Com base nesta contextualização inicial sobre o hipertexto é possível, ainda, pelas reflexões apontadas por Lévy (1993, p. 25-26, grifo nosso), desvelar as dinâmicas inerentes a este conceito por meio de seis princípios abstratos:

1. Princípio da metamorfose: A rede hipertextual está em constante construção e renegociação. [...]

2. Princípio da heterogeneidade: Os nós e as conexões de uma rede hipertextual são heterogêneos. [...]

3. Princípio da multiplicidade e de encaixe das escalas: [...] qualquer nó ou conexão, quando analisado, pode revelar-se como sendo composto por toda uma rede, e assim por diante, indefinidamente, ao longo da escala dos graus de precisão. [...]

4. Princípio da Exterioridade: A rede não possui unidade orgânica, nem motor interno. [...]

5. Principio da Topologia: Nos hipertextos, tudo funciona por proximidade, por vizinhança. Neles, o curso dos acontecimentos é uma questão de topologia, de caminhos. [...]

6. Princípio da mobilidade dos centros: A rede não tem centro, ou melhor, possui permanentemente diversos centros [...].

Ligado geneticamente à metáfora do hipertexto tem-se o conceito de "rede", que carrega consigo a necessidade de apreensão da lógica que está subjacente à metáfora

1 As siglas presentes nesta citação significam, respectivamente: Personal Computer, Computador Conectado, Computador Conectado Móvel. 
hipertextual. Aqui, pontua-se a sistematização acerca da ideia de rede proposta por Teixeira (2010), e por meio desta objetiva-se desvelar as relações inerentes entre a lógica das redes com os fenômenos da cibercultura expressos por Lemos (2003) e as compreensões acerca dos processos hipertextuais proposta por Lévy (1993). Nestes termos, Teixeira (2010, p. 31) define rede como uma

[...] estrutura dinâmica e aberta, cuja condição primeira de existência é a ação dos nós que a formam e que, ao construírem suas próprias formas de apropriação e de ação sobre a trama, modificam-na e por ela são modificados. Sua função básica é dar suporte ao estabelecimento de relações comunicacionais e colaborativas entre seus nós [...].

Com base nesta compreensão é possível verificar que as principais características que marcam a lógica das redes são: a atividade dos nós que compõem a estrutura reticular, a complexidade inerente à composição de uma rede e a dinamicidade dos processos de (re)configuração da rede segundo as demandas exigidas. Logo, para Teixeira (2010, p. 31), o que está em jogo quando se trata da lógica das redes é a necessidade de que cada pessoa, imersa no contexto tecnológico-cultural contemporâneo, tem de assumir-se como um nó da trama reticular, ou seja, reconhecer-se como autor de sentidos, informações, ideias. A lógica das redes requer, invariavelmente, uma ruptura com a passividade característica dos meios de comunicação de massa que operam em uma lógica de distribuição de informações e entendimentos sobre a realidade nos moldes de um para todos.

Por meio dos conceitos de hipertexto e de lógica das redes torna-se possível verificar algumas questões referentes ao ciberespaço e a sua linguagem natural, a hipermídia, bem como especificar as dinâmicas dos movimentos sociais de construção conjunta dos fluxos de informações que criam e moldam este novo espaço, partindo-se aqui do conceito de inteligência coletiva. Para Santaella (2004, p. 45), o ciberespaço pode ser definido como

[...] todo e qualquer espaço informacional multidimensional que, dependente da interação do usuário, permite a este o intercâmbio de seus fluxos codificados de informação. Assim sendo, o ciberespaço é o espaço que se abre quando o usuário conecta-se com a rede.

Neste universo virtual de comunicação e de fluxo de informações, a revisão dos conceitos de espaço e de tempo parece pertinente na medida em que o seu surgimento possibilitou o acesso a um novo tipo de território onde medidas como a distância foram anuladas. Ainda, na sociedade contemporânea marcada pela cibercultura, os artefatos 
tecnológicos acabam por proporcionar uma vivência de processos que ocorrem em tempo real, ou seja, um tempo imediato, “live”, que, consequentemente, traz em seu interior a ideia de transformação do espaço de lugar, onde impera o tempo cronológico. Criam-se nesse contexto, segundo Lemos (2003, p. 14), “[...] espaços de fluxos, redes planetárias pulsando no tempo real, em caminho para a desmaterialização do espaço de lugar”.

Ligado ao conceito de ciberespaço tem-se a ideia da linguagem que molda este ambiente, ou seja, a hipermídia. De acordo com Machado (apud SILVA, 2002, p. 149), a hipermídia pode ser caracterizada da seguinte forma:

Do hipertexto passa-se hoje a hipermídia, que é uma forma 'tridimensional' combinatória, permutacional e interativa de multimídia, onde textos, sons e imagens (estáticas ou em movimento) estão ligados entre si por elos probabilísticos e móveis, que podem ser configurados pelos receptores de diferentes maneiras, de modo a compor obras instáveis em quantidades infinitas.

Nestes termos, partindo dos estudos de Santaella (2004, p. 48), destacam-se inicialmente dois traços definidores da hipermídia: a "hibridização de linguagens, processos sígnicos, códigos e mídias”; “[...] a organização reticular de fluxos informacionais em arquiteturas hipertextuais”. Ambos, porém, assentam-se sobre uma terceira característica fundamental da hipermídia: a interatividade. Nesse sentido, e segundo a concepção proposta por Silva, o conceito de interatividade pontua que

[...] um produto, uma comunicação, um equipamento, uma obra de arte, são de fato interativos quando estão imbuídos de uma concepção que contemple complexidade, multiplicidade, não-linearidade, bidirecionalidade, potencialidade, permutabilidade (combinatória), imprevisibilidade, etc., permitindo ao usuário-interlocutor-fruidor a liberdade de participação, de intervenção, de criação (2002, p. 100).

Nesta nova perspectiva de interatividade, o leitor não é mais um simples receptor de informações e sentidos, mas possui a capacidade de participar-intervir no modo como o processo comunicativo está sendo conduzido. Já o escritor não emite tão somente uma mensagem fechada, não flexível e sem possibilidades de intervenção por parte do leitor, mas propõe um conjunto de possíveis caminhos, vias de acesso e sinalizações por onde o leitor poderá construir seus sentidos. (SILVA, 2002, p. 101-112). Ainda, no que se refere à bidirecionalidade-hibridação é possível afirmar que só existe comunicação interativa “[...] a partir do momento em que não há mais nem emissor nem receptor e, a partir do momento que 
todo emissor é potencialmente um receptor e todo receptor é potencialmente um emissor”. (SILVA, 1998, p. 3). Por fim, o binômio potencialidade-permutabilidade disserta sobre a capacidade que os sistemas hipermídia possuem ao permitirem a combinação de informação e a consequente produção de narrativas potencialmente infinitas. (SILVA, 2002, p. 131).

Por meio das características interativas da hipermídia, além de estabelecer e modificar links de um modo não pensado pelo autor original da hipermídia, o leitor-navegador poderá, em um nível superior de coautoria, acrescentar ou modificar os nós da malha reticular. Ao atingir este nível de possibilidades interativas de cocriação, as redes de documentos hipermidiais e as tecnologias que tornam possível sua composição configuram-se efetivamente como poderosos instrumentos de escrita-leitura coletiva. Isto é, de composição de conhecimentos e comunicações por meio de processos de autoria colaborativa e inteligência coletiva. (LÉVY, 1999, p. 57).

Nestes termos, Lévy conceitua inteligência coletiva como “[...] uma inteligência distribuída por toda a parte, incessantemente valorizada, coordenada em tempo real, que resulta em uma mobilização efetiva das competências”. (2003, p. 28, grifo do autor). A inteligência coletiva parte do princípio de que todo o conhecimento existente está contido na própria humanidade, pulsa em cada ser humano que possui um conjunto de campo de saberes, experiências e aprendizados determinados. Para que a inteligência coletiva seja possível, torna-se necessário a aplicação de novas ferramentas digitais de comunicação e informação capazes de fornecerem "[...] aos membros de uma comunidade os meios de coordenar suas interações no mesmo universo virtual de conhecimentos”. (LÉVY, 2003, p. 29).

Por meio do ciberespaço e das tecnologias hipermídia, que se constituem como sua linguagem, permite-se atualmente que diversas pessoas situadas ao redor do mundo, com afinidades e interesses em comum, iniciem processos interativos de comunicação coordenados em tempo real no interior de coletivos inteligentes. Em síntese, por meio destas tecnologias seria possível alcançar o objetivo central da inteligência coletiva, ou seja, “[...] o reconhecimento e o enriquecimento mútuos das pessoas, e não o culto de comunidades fetichizadas ou hipostasiadas”. (LÉVY, 2003, p. 29).

Por fim, partindo da análise efetivada sobre o contexto sociocultural contemporâneo e a emergência de uma inteligência coletiva, torna-se possível conceituar a acepção “Tecnologias Digitais de Rede”. Apropriando-se inicialmente do conceito de “Tecnologias de Rede” proposto por Teixeira (2010, p. 29), e adicionando à terminologia o caráter digital que estas tecnologias possuem (LÉVY, 1999, p. 31-75), as Tecnologias Digitais de Rede podem 
ser compreendidas como os ambientes hipermidiais de comunicação interativa, multidirecional e rizomática que surgem com o advento do ciberespaço e que permitem o estabelecimento de processos de autoria colaborativa e protagonismo de cada nó pertencente a uma determinada rede, engendrando, portanto, a inteligência coletiva que sintetiza a ideia do movimento social de apropriação crítica e criativa destas tecnologias na cibercultura.

\section{Projetos de ensino-aprendizagem: busca de ressignificações das práticas educacionais}

Ao iniciar o debate sobre metodologias de ensino-aprendizagem, parece pertinente no contexto do presente trabalho identificar alguns postulados históricos e pedagógicos básicos que desvelam as origens pedagógicas da ideia de um sistema didático por projetos. Nesse sentido, é possível afirmar que tais considerações educacionais nascem primeiramente no interior do denominado Movimento de Renovação Pedagógica, ou simplesmente Escola (Educação) Nova. Este movimento, que reuniu diversos educadores importantes do século XIX e XX, tais como John Dewey, Maria Montessori, Óvide Drecoly, Édouard Claparède, e Adolphe Ferriére, teve como princípio fundamental a crítica ao ensino então vigente, ou seja, “[...] a educação nova toma como ponto de partida as decepções e lacunas que se apresentavam como características da educação tradicional”. (SNYDERS, 1974, p. 69).

Com base neste ponto nevrálgico, compartilhado por todos os teóricos do movimento renovador, é possível desmembrar os principais itens criticados e que constituiriam, portanto, o que fora denominado "Ensino ou Escola Tradicional”: os conteúdos pré-programados, hierarquizados e dissociados da realidade dos alunos; os métodos de ensino ultrapassados; a concepção de criança como adulto em miniatura; as lições como centro da rotina escolar. (BARBOSA, 2000, p. 77).

Partindo destas considerações, os diversos autores ligados ao movimento renovador interpretaram estes pontos segundo suas próprias concepções educativas. No contexto das reflexões sobre a utilização de projetos de pesquisa como método de ensino-aprendizagem, é possível citar em especial o filósofo estadunidense John Dewey. Por intermédio das ideias pioneiras deste autor e, posteriormente, do seu discípulo William Kilpatrick foram sistematizadas as diretrizes teóricas e práticas do que viria a ser o Sistema de Projetos ou Método de Projetos. (DEWEY, 1959; KILPATRICK, 1918; LOURENÇO FILHO, 1978). Portanto, nasce uma metodologia de ensino-aprendizagem que tem como referência teóricoprática a utilização da pesquisa na educação, ou seja, um método pedagógico baseado na “[...] 
procura da solução de um ato problemático levado à realização completa em um ambiente real tendo um compromisso com a transformação da realidade”. (BARBOSA, 2000, p. 78).

Tomando como base a contribuição original de Dewey e Kilpatrick, diversos autores ligados à área da pedagogia incidiram seu olhar sob a proposta de um sistema didático por projetos, ocorrendo assim, ao longo do século XX, ressignificações deste método de ensinoaprendizagem. No escopo deste trabalho, julga-se necessário citar duas das principais interpretações surgidas, desenvolvidas por Fernando Hernández (Projetos de Trabalho) e Léa da Cruz Fagundes (Projetos de Aprendizagem). Com base em algumas categorias advindas das principais problemáticas envolvidas no processo educativo, são analisados, na Tabela 1, os sistemas didáticos de projetos concebidos por Dewey/Kilpatrick, Hernández e Fagundes.

\begin{tabular}{|c|c|c|c|}
\hline $\begin{array}{l}\text { Pressupostos } \\
\text { teóricos. }\end{array}$ & $\begin{array}{c}\text { Sistema ou Método de } \\
\text { Projetos. }\end{array}$ & $\begin{array}{l}\text { Projetos de } \\
\text { Trabalho. }\end{array}$ & $\begin{array}{c}\text { Projetos de } \\
\text { Aprendizagem. }\end{array}$ \\
\hline $\begin{array}{l}\text { Papel professor X } \\
\text { aluno. }\end{array}$ & $\begin{array}{l}\text { Professor como } \\
\text { criador do ambiente } \\
\text { da aprendizagem. } \\
\text { Aluno, por meio da } \\
\text { sua atividade } \\
\text { espontânea, vai } \\
\text { direcionando a } \\
\text { aprendizagem. }\end{array}$ & $\begin{array}{l}\text { Professor como } \\
\text { estimulador e } \\
\text { cooperador em } \\
\text { áreas do } \\
\text { conhecimento a } \\
\text { serem } \\
\text { compreendidas } \\
\text { pelo aluno. Aluno } \\
\text { deve visar à } \\
\text { compreensão e a } \\
\text { globalização dos } \\
\text { saberes trabalhados } \\
\text { em um projeto. }\end{array}$ & $\begin{array}{l}\text { Professor atua como } \\
\text { ativador da } \\
\text { aprendizagem, } \\
\text { articulador, } \\
\text { orientador e } \\
\text { especialista. Aluno é } \\
\text { um ser ativo na } \\
\text { construção dos } \\
\text { conhecimentos } \\
\text { envolvidos em um } \\
\text { projeto. }\end{array}$ \\
\hline $\begin{array}{l}\text { Entendimento sobre } \\
\text { a aprendizagem. }\end{array}$ & $\begin{array}{l}\text { Parte do } \\
\text { instrumentalismo de } \\
\text { John Dewey (mente } \\
\text { como uma ferramenta } \\
\text { utilizada para a } \\
\text { adaptação à realidade) } \\
\text { e da psicologia da } \\
\text { aprendizagem de } \\
\text { Edward L. Thorndike. }\end{array}$ & $\begin{array}{l}\text { Ensino para a } \\
\text { compreensão e para } \\
\text { a globalização dos } \\
\text { saberes. }\end{array}$ & $\begin{array}{l}\text { Construtivismo de } \\
\text { Jean Piaget e } \\
\text { Construcionismo de } \\
\text { Seymour Papert. }\end{array}$ \\
\hline $\begin{array}{l}\text { Escolha do } \\
\text { tema/problema de } \\
\text { pesquisa. }\end{array}$ & $\begin{array}{l}\text { Deve partir do aluno, } \\
\text { de seu interesse } \\
\text { exclusivo. }\end{array}$ & $\begin{array}{l}\text { Pode ser sugerida } \\
\text { pelo(s) aluno(s) } \\
\text { e/ou professores. } \\
\text { Crítica ao } \\
\text { espontaneísmo } \\
\text { exacerbado } \\
\text { defendido na } \\
\text { Escola Nova. }\end{array}$ & $\begin{array}{l}\text { A pergunta que } \\
\text { desencadeia o } \\
\text { processo de pesquisa } \\
\text { deve se basear no } \\
\text { interesse exclusivo } \\
\text { do aluno. }\end{array}$ \\
\hline
\end{tabular}


Vitor Malaggi - Karina Marcon - Adriano Canabarro Teixeira

\begin{tabular}{|c|c|c|c|}
\hline $\begin{array}{l}\text { Definição de } \\
\text { momentos-chave } \\
\text { para o } \\
\text { desenvolvimento dos } \\
\text { projetos. }\end{array}$ & $\begin{array}{l}\text { Reconhece no modelo } \\
\text { do método de ensino } \\
\text { postulado pela Escola } \\
\text { Nova uma série de } \\
\text { sugestões sobre } \\
\text { momentos possíveis } \\
\text { de um projeto: seleção } \\
\text { do problema/questão, } \\
\text { busca de informações } \\
\text { e o tratamento destas } \\
\text { etc. }\end{array}$ & $\begin{array}{l}\text { Não admite o } \\
\text { estabelecimento de } \\
\text { passos rígidos, nem } \\
\text { do uso da palavra } \\
\text { “método” para } \\
\text { caracterizar uma } \\
\text { sequencia universal } \\
\text { a ser seguida } \\
\text { durante o } \\
\text { desenvolvimento } \\
\text { de um projeto. }\end{array}$ & $\begin{array}{l}\text { Caracteriza uma } \\
\text { série de momentos- } \\
\text { chave a serem } \\
\text { realizados para o } \\
\text { desenvolvimento de } \\
\text { um Projeto de } \\
\text { Aprendizagem: } \\
\text { escolha da Questão } \\
\text { de Investigação, } \\
\text { levantamento das } \\
\text { dúvidas temporárias } \\
\text { e certezas } \\
\text { provisórias etc. }\end{array}$ \\
\hline $\begin{array}{l}\text { Centralidade do } \\
\text { processo de ensino- } \\
\text { aprendizagem. }\end{array}$ & Aluno. & $\begin{array}{l}\text { Alunos e } \\
\text { professores. }\end{array}$ & Aluno. \\
\hline $\begin{array}{lll}\text { Visão } & \text { sobre } & \text { o } \\
\text { currículo escolar. } & \end{array}$ & $\begin{array}{l}\text { Opta-se pela } \\
\text { necessidade de } \\
\text { integração curricular. }\end{array}$ & $\begin{array}{l}\text { Globalização das } \\
\text { disciplinas vista } \\
\text { como ponto-chave } \\
\text { do processo } \\
\text { educativo via } \\
\text { projetos. }\end{array}$ & $\begin{array}{l}\text { Disciplinas não } \\
\text { devem ser } \\
\text { consideradas de } \\
\text { maneira isolada, pois } \\
\text { um problema de } \\
\text { pesquisa pode } \\
\text { necessitar a } \\
\text { interação de diversas } \\
\text { disciplinas. }\end{array}$ \\
\hline
\end{tabular}

Tabela 1 - Comparação os sistemas didáticos baseados em projetos de

Dewey/Kilpatrick, Hernández e Fagundes.

Fontes: Kilpatrick (1918); Dewey (1959); Lourenço Filho (1978); Fagundes, Sato e Maçada (1999); Hernández (1998).

Partindo da análise efetivada da Tabela 1, é possível trazer para a discussão a proposta dos Projetos de Ensino-Aprendizagem. Neste contexto, uma questão pertinente seria: em que a proposta dos PEAs se difere dos sistemas destacados na Tabela 1? De maneira sintética, é possível afirmar que a principal diferença entre as concepções de Dewey/Kilpatrick, Hernández e Fagundes com relação aos Projetos de Ensino-Aprendizagem seria o embasamento teórico proveniente da Teoria Histórico-Cultural, que tem em Lev S. Vigotsky seu principal expoente, bem como a tentativa de imbricação dos PEAs com conceitos, metáforas e linguagens advindas dos estudos sobre as Tecnologias Digitais de Rede (TDRs). Nestes termos, tem-se por um lado a busca por uma sistematização de metodologia de processo de ensino-aprendizagem por projetos que levem em conta os postulados teóricos de Vigotsky, e as implicações pedagógicas advindas deles e, de outro, a tentativa de convergir esta base pedagógica com uma apropriação crítica das TDRs enquanto recursos que possibilitam potencializar as práticas educativas via PEAs. 
Inicialmente, deve-se frisar que o objetivo educacional principal, com base na utilização dos PEAs, é o de ressaltar a importância dos processos de ensino-aprendizagem realizados na escola. Estes processos têm papel fundamental na ascensão dos alunos em níveis cada vez maiores e mais qualificados de interação com o mundo, a cultura e os seres sociais, promovendo as condições para o desenvolvimento cognitivo do aluno e a sua ascensão às formas mais elevadas de pensamento conceitual. (VIGOTSKI, 1991; 1998). Assim, a Teoria Histórico-Cultural provê um suporte teórico aos PEAs para a reflexão dos papéis primordiais da internalização da cultura, via interação social que envolve ações cognitivas intersubjetivas, de cooperação e a colaboração, na ocorrência dos processos de ensino-aprendizagem que acabam por influenciar todo o desenvolvimento psicológico do ser humano. (OLIVEIRA, 1997).

Outro ponto de discussão importante são as relações pedagógicas redefinidas entre os dois sujeitos principais envolvidos no processo de ensino-aprendizagem escolar: o professor e o aluno. Nos PEAs estes papéis são visualizados nos seguintes termos: o aluno deve ser considerado um ser ativo na apropriação dos conhecimentos advindos da cultura organizada e que são ensinados na escola, o que pressupõe considerar o aprendiz capaz de realizar processos de análise, síntese, reflexão, interpretação e interligação dos conceitos advindos das disciplinas escolares, possibilitando uma apropriação original dos significados inerentes a estes conceitos. (VIGOTSKI, 1991, p. 49).

Ainda, os PEAs postulam que o papel da intervenção pedagógica exercida pelo professor é um fator importante e essencial do processo formativo-educacional, visto que é por meio desta intervenção que os processos de ensino-aprendizagem irão acontecer, criando as condições para a constituição da Zona de Desenvolvimento Proximal (ZDP). Estas ações, por sua vez, possibilitam o desencadeamento do desenvolvimento psicológico nos alunos. (VIGOTSKI, 1998, p. 95-101). Porém, essa intervenção não deve ser considerada uma mera transmissão de conceitos, valores e significados do professor para o aluno. Ao contrário disso, a intervenção serve para que seja estabelecido um ponto de discussão, de diálogo, de interação que acaba por proporcionar os elementos necessários para que o processo de ensinoaprendizagem ocorra.

Por fim, os PEAs optam por uma organização espaço-tempo horizontal, permanentemente negociada entre todos os envolvidos com os processos de ensinoaprendizagem escolares. Nestes termos, uma organização homogeneizada e massificada dos espaços de aprendizagem por turmas seriadas, baseadas em uma hierarquização conectadas à 
defesa de um contato e progressão linear dos alunos com os conteúdos escolares, deve ser substituída por uma organização flexível e dinâmica permanentemente negociada entre os envolvidos nos processos educativos. Assim, a organização escolar deve levar em consideração o fato de que em um currículo organizado por projetos a diversidade de mobilizações e interesses que dá origem as pesquisas pressupõe a capacidade de apropriação diferenciada dos respectivos espaços e tempos. (FAGUNDES, SATO; MAÇADA, 1999).

Em uma visão geral, o desenrolar de um PEA pode acontecer baseado em alguns momentos-chave, conforme detalhado no Quadro 1.

\begin{tabular}{|c|c|}
\hline Momento-chave & Descrição \\
\hline Problematização. & $\begin{array}{l}\text { A problematização é um momento onde o diálogo e o debate entre } \\
\text { professor e aluno ocorrem de modo intenso, visto que estes dois sujeitos } \\
\text { deverão negociar o que será objeto de estudo, levando em consideração } \\
\text { o interesse do aluno, por um lado, bem como também a necessidade do } \\
\text { professor de realizar um encaminhamento pedagógico às proposições } \\
\text { iniciais e mais gerais dos alunos. }\end{array}$ \\
\hline $\begin{array}{l}\text { Definição da rede } \\
\text { de conceitos } \\
\text { espontâneos. }\end{array}$ & $\begin{array}{l}\text { Os alunos deverão realizar um levantamento prévio (em diálogo com o } \\
\text { professor) do que já sabem sobre a problematização proposta, ou seja, } \\
\text { deverão definir a rede de conceitos espontâneos que possuem, em } \\
\text { diversas áreas do conhecimento, e que julgam estar relacionada a esta } \\
\text { problematização. }\end{array}$ \\
\hline $\begin{array}{c}\text { Definição das } \\
\text { indagações-guias. }\end{array}$ & $\begin{array}{l}\text { Definição de um conjunto de dúvidas e questionamentos que partam do } \\
\text { problema geral proposto e que, baseando-se na rede de conceitos } \\
\text { espontâneos do aluno, juntamente com um diálogo e negociação com o } \\
\text { professor, permita ao discente analisar e refletir sobre possíveis } \\
\text { conhecimentos necessários de serem estudados para que a } \\
\text { problematização possa ser resolvida. }\end{array}$ \\
\hline $\begin{array}{l}\text { Mapa dos } \\
\text { possíveis. }\end{array}$ & $\begin{array}{l}\text { O professor, com base nos levantamentos dos conhecimentos prévios } \\
\text { dos alunos e das suas indagações deverá sistematizar as possíveis áreas } \\
\text { do conhecimento e, dentro destas, os conceitos e categorias específicos } \\
\text { que potencialmente podem ser referenciados e necessários à execução de } \\
\text { um determinado projeto. }\end{array}$ \\
\hline \multirow{2}{*}{ Desenvolvimento. } & $\begin{array}{l}\text { Aluno: por intermédio da sua atividade cognitiva de analisar, } \\
\text { sistematizar, compreender e interligar as informações, baseando-se na } \\
\text { colaboração e coautoria com professores e colegas, vai se apropriando e } \\
\text { estahelecendo relacões entre ns conhecimentos. }\end{array}$ \\
\hline & $\begin{array}{l}\text { Professor: atuará como um especialista em sua área de conhecimento, } \\
\text { intervindo nos processos de ensino-aprendizagem e, consequentemente, } \\
\text { na ZDP dos alunos. }\end{array}$ \\
\hline $\begin{array}{c}\text { Socialização e } \\
\text { avaliação. }\end{array}$ & $\begin{array}{l}\text { A socialização e avaliação devem ser realizadas durante todo o percurso } \\
\text { de um PEA, não como uma maneira de controlar, qualificar ou } \\
\text { classificar, mas sim para reorientar o processo de ensino-aprendizagem } \\
\text { quando preciso, para que este caminhe cada vez mais em direção à } \\
\text { apropriação dos conhecimentos. }\end{array}$ \\
\hline
\end{tabular}

Quadro 1 - Pontos essenciais no desenvolvimento de um PEA. 
Em conclusão, destaca-se que estes momentos não devem ser realizados como uma sequencia rígida e linear de passos, mas deve-se, sim, adaptá-los as demandas específicas emanadas de cada PEA.

\section{Ressignificando os papéis de professores e alunos na experiência de desenvolvimento de PEAs via apropriação das TDRs}

Sobre as mudanças necessárias à Educação imersa em uma sociedade condicionada pela emergência da cibercultura, é possível recordar a recomendação de Lévy (1997, p. 33) para que se aprenda “[...] com o movimento contemporâneo das técnicas”. Ou seja, faz-se premente compreender as características inerentes das TDRs tornando possível verificar como estas podem ressignificar pressupostos educacionais. Deste modo, tanto o professor quanto o aluno deverão aprender com o desafio do digital, oportunizando meios para o estabelecimento de um modelo educacional que se aproprie do movimento contemporâneo das técnicas.

É nestes termos que a proposta de ressignificação da apropriação dos Projetos na Educação, a qual foi denominada de Projetos de Ensino-Aprendizagem, deve ser compreendida: como um ponto de partida de reflexões e estudos que visam abrir possibilidades para o estabelecimento da união entre pressupostos educacionais que vão ao encontro das características das TDRs. Logo, partindo deste objetivo, é possível frisar uma das discussões pedagógicas centrais deste contexto de reflexões: a problemática da relação professor-aluno e a consequente ressignificação dos papéis de docentes e discentes pela incorporação pedagógica das características TDRs no contexto de desenvolvimento de PEAs.

Baseado nestas considerações, os PEAs visam a constituir uma relação professor-aluno fundada na lógica das redes e nos princípios do hipertexto. Portanto, procura-se na prática educativa via PEAs a criação de redes de ensino-aprendizagem, tomando para isso o aporte das TDRs com o objetivo de apropriar-se de todo o seu potencial para o estabelecimento de processos interativos. Nestes processos educativos interativos, além de professores e alunos, a rede estabelecida poderá ser ocupada por instituições, outros sujeitos espalhados pelo mundo, ideias, teorias, baseando-se assim no Princípio da Heterogeneidade proposto como caracterização do hipertexto por Lévy (1993). É possível aprofundar esta discussão trazendo para o debate dois pontos elencados por Serpa (2004, p. 173) ao relatar sobre a pedagogia intrínseca às novas tecnologias: 
Vitor Malaggi - Karina Marcon - Adriano Canabarro Teixeira

Não há centro - os processos, conforme as condições, têm uma centralidade instável. Ora o professor é o centro, ora o aluno, ora outro ator diferente de professor e aluno.

Processos horizontais - a hierarquia e verticalidade, próprias da cultura pedagógica, são incompatíveis com a lógica e a pedagogia das Novas Tecnologias, pois estas funcionam em rede.

Encontram-se nestas reflexões o Princípio da Mobilidade dos Centros e o Princípio da Heterogeneidade, levantados por Lévy (1993, p 25-26); esses são apropriados na concepção pedagógica proposta por Serpa e, efetivamente, essa posição também é tomada pelos PEAs. Nas sistematizações dos pressupostos educacionais dos PEAs opta-se claramente pela necessidade constante de negociações envolvendo professores e alunos. Da escolha do tema que irá desencadear um PEA à seleção de possíveis TDRs a serem apropriadas para possibilitar processos essencialmente interativos durante o transcorrer das atividades, a horizontalidade, a argumentação e o diálogo constante entre docentes e discentes embasam a proposta dos PEAs.

Assim, o ambiente que emana quando se estabelecem redes de ensino-aprendizagem necessita, invariavelmente, de uma nova postura de professores e alunos enquanto sujeitos do processo de ensino-aprendizagem. Como metáfora explicativa, o conceito de interatividade pode ser apropriado na problemática do ambiente educacional dos PEAs para o estudo sobre a atuação de professores e alunos nos processos de ensino-aprendizagem.

Uma reflexão inicial pode ter por base as colocações de Marchand (apud SILVA, 2000, p. 1), sendo que para este autor a interatividade pressupõe que

O emissor não emita mais no sentido que se entende habitualmente. Ele não propõe mais uma mensagem fechada, ao contrário, oferece um leque de possibilidades, que coloca no mesmo nível, conferindo a elas um mesmo valor e um mesmo estatuto. O receptor não está mais em posição de recepção clássica. A mensagem só toma todo o seu significado sob a sua intervenção. Ele se torna, de certa maneira, criador. Enfim, a mensagem que agora pode ser recomposta, reorganizada, modificada em permanência sob o impacto cruzado das intervenções do receptor e dos ditames do sistema, perde seu estatuto de mensagem 'emitida'.

Recorrendo ao conceito de interatividade e a reflexão proposta por Marchand, uma primeira questão a ser pontuada é que o professor, entendido como emissor de verdades, de informações, conceitos e valores a serem memorizados pelos alunos perde o seu sentido de existência pedagógica. Do mesmo modo, um professor passivo, que baseia sua atividade pedagógica no “deixar fazer” do aluno, em seu espontaneísmo e livre atividade, também não 
está em correspondência com os preceitos da interatividade. De outro lado, o receptor, ou seja, a compreensão clássica do aluno, como sujeito que recebe passivamente as informações repassadas do professor, deixa de existir em um ambiente educacional permeado pela perspectiva da interatividade. Como bem ressalta Silva e Claro (2007, p. 85), o aprendiz em um ambiente educacional embasado pela concepção da interatividade

[...] não atuará mais como receptor de conhecimentos a serem reproduzidos no dia da prova. Ele adentra e opera com os conteúdos da aprendizagem propostos pelo professor. Nele inscreve sua emoção, sua intuição, seus anseios, seu gosto, sua imaginação, sua inteligência, na perspectiva de coautoria.

Em suma, pela atividade de cooperação que se estabelece entre professores e alunos, ou seja, pelos papéis de emissão e recepção ressignificados segundo os pressupostos da interatividade, o ensino-aprendizagem vai ocorrendo via processos que considerem o caráter coletivo e de partilha de conhecimentos, o que no âmbito dos PEAs é corroborado pela compreensão vigotskiana do fenômeno educacional. (VIGOTSKI, 1998).

Um ponto teórico a ser analisado neste contexto, referente à mudança do papel do aluno, tem conexão com a necessária compreensão de como seus interesses e o seu ritmo de aprendizagem, que é peculiar de cada sujeito, pode encontrar nos PEAs potencializados pelas TDRs uma nova abordagem de respeito às diferenças e subjetividades de cada aluno. Novamente pode-se trazer a questão da lógica das redes e do hipertexto para este debate, pois um ambiente educacional baseado nos seus pressupostos leva em conta a horizontalidade dos processos e a negociação permanente entre professores e alunos, como bem relata Serpa (2004) ao caracterizar os princípios da mobilidade dos centros e da participação necessária na pedagogia intrínseca às novas tecnologias.

Nesses termos, os interesses dos alunos e os seus ritmos de aprendizagem podem ser respeitados neste ambiente educacional emanado da união entre PEAs e TDRs, pois na rede de ensino-aprendizagem que se estabelece a lógica de massificação é rompida e, assim, não há mais uma transmissão unidirecional de informações do professor para o aluno, informações estas já pré-definidas mesmo antes do professor entrar em sala de aula. Na lógica das redes de ensino-aprendizagem, a necessária negociação entre professores e alunos para a delimitação sobre o que um projeto versará, quais TDRs poderão ser apropriadas neste processo, que sujeitos fora dos limites da sala de aula poderão participar da apropriação dos saberes, e em que tempo-espaço ocorrerão os processos de ensino-aprendizagem, provê um ambiente onde 
os interesses e ritmos dos alunos possam ser respeitados em sua integridade.

Ainda no que se refere ao aluno e a seus interesses no processo de participaçãointervenção nos processos de ensino-aprendizagem, é possível novamente recordar a característica essencialmente interativa das TDRs hipermidiais. O professor no ambiente dos PEAs não mais transmite conteúdos a serem memorizados pelos alunos, mas disponibiliza uma rede de possíveis conexões, onde conteúdos, ideias, teorias e conceitos estão interligados com base em um determinado contexto. Tomando por base a característica própria da hipermídia, que requer a participação-intervenção do aluno no processo de (re)criação constante da rede estabelecida, pode-se dizer que o aluno também se apropria desta teia de relações percorrendo e intervindo conforme seu interesse e ritmos, e que isso conduz a compreensão de que os alunos podem se apropriar da rede proposta pelo professor de diferentes maneiras. Contudo, frisa-se, sempre com a devida intervenção do professor como proponente e colaborador no estabelecimento dos possíveis caminhos de aprendizagem e nas apropriações dos conceitos a serem trabalhados em um projeto.

Portanto, o papel do professor é reconhecido como essencialmente necessário, na condição de mediador do processo de ensino-aprendizagem. Atuando com base nos pressupostos psicológicos de Vigotsky e dos binômios da interatividade, o professor torna-se “[...] o agente mediador do processo de aprendizagem e, com suas intervenções e provocações, contribui decisivamente para o fortalecimento de funções ainda não consolidadas, ou para a abertura de zonas de desenvolvimento proximal”. (SILVA; CLARO, 2007, p. 83). Para tanto, o docente deve levar em conta o desenvolvimento de pelo menos cinco habilidades:

- Pressupor a participação-intervenção dos alunos, sabendo que participar é muito mais que responder 'sim' ou 'não', é muito mais que escolher uma opção dada; participar é atuar na construção do conhecimento e da comunicação;

- Garantir a bidirecionalidade da emissão e da recepção, sabendo que a comunicação e a aprendizagem são produzidas pela ação conjunta do professor e dos alunos;

- Disponibilizar múltiplas redes articulatórias, sabendo que não se propõe uma mensagem fechada, ao contrário, se oferece informações em redes de conexões, permitindo ao receptor ampla liberdade de associações, de significações;

- Engendrar a cooperação, sabendo que a comunicação e o conhecimento se constroem entre alunos e professores como co-criação e não no trabalho solitário.

- Suscitar a expressão e a confrontação das subjetividades, sabendo que a fala livre e plural supõe lidar com as diferenças na construção da tolerância e 
Vitor Malaggi - Karina Marcon - Adriano Canabarro Teixeira

da democracia (SILVA, 2001, p. 5).

Conforme o que foi discutido até então sobre o papel do professor ressignificado no ambiente de apropriação das TDRs e suas características pelos PEAs, é possível citar dois termos criados por Silva (2002) e Ramal (2002) que expressam as funções e a natureza do trabalho a ser desenvolvido pelos docentes, respectivamente: o professor como designer pedagógico e como dinamizador da inteligência coletiva.

Na primeira concepção levantada por Silva (2002), o professor deve disponibilizar os conteúdos de ensino-aprendizagem (ideias, teorias, conceitos) em espaços de participação e construção coletiva de saberes, cuidando para que a materialidade da ação educacional interativa ocorra por intermédio da coautoria que os alunos estabelecem com base nos múltiplos percursos que o professor planeja em forma de redes de ensino-aprendizagem potenciais. (SILVA, 2002, p. 73). Nestas redes o professor não é relegado a um papel relacionado a um mero assistir ao aluno que age e se movimenta sozinho nos espaços reticulares que ele institui. Vai além disso: o professor deve afirmar-se também como um nó da rede com potencial para, em diversos momentos, assumir a centralidade dos processos de ensino-aprendizagem e conduzir os alunos para que possam alcançar a compreensão dos significados em jogo a serem apropriados, caminhando assim para a formação dos conceitos que compõem as disciplinas que gravitam em torno de um PEA.

Traz-se por fim o conceito do professor como um dinamizador da inteligência coletiva proposto por Ramal (2002, p. 206-227), o qual irá caracterizar o docente como sendo

(a) responsável pelo gerenciamento de processos de construção cooperativa do saber, (b) transformando grupos escolares heterogêneos em comunidades inteligentes, flexíveis, autônomas e felizes, (c) integrando as múltiplas competências dos estudantes com base em diagnósticos permanentes, (d) convidando ao diálogo interdisciplinar e intercultural nas pesquisas realizadas, (e) promovendo a abertura dos espaços e dos tempos de aprendizagem para além da sala de aula e estimulando a comunicação interpessoal por meio da pluralidade de linguagens e expressões.

Nestes termos, com base na ideia do professor como um dinamizador da inteligência coletiva, julga-se possível derivar características e pontos teóricos essenciais para os PEAs, tais como a compreensão dos processos de aprendizagem conforme os postulados de Vigotsky, a necessidade de compreender os estudantes como seres singulares com ritmos e interesses diferenciados, bem como a proposta de avaliação constante da trajetória de aprendizagem dos alunos com base em diagnósticos que analisem mais os processos do que 
um produto final.

\section{Análise de uma experiência empírica de busca pela ressignificação das relações professores-alunos}

Por intermédio das construções teóricas realizadas, é possível delimitar o conjunto de ideias e práticas que embasaram o desenvolvimento de um processo empírico de pesquisa, tomando como norteadores as concepções de imbricação entre Projetos de EnsinoAprendizagem e Tecnologias Digitais de Rede.

\section{Metodologia da Pesquisa Empírica}

O lócus da pesquisa foi a Escola Estadual de Ensino Fundamental Capistrano de Abreu, localizada no município de Soledade - RS. Foram selecionados oito sujeitos a serem investigados, derivados da $2^{\mathrm{a}}$, $3^{\mathrm{a}}$ e $4^{\mathrm{a}}$ séries do turno da manhã, ano letivo de 2009/( ${ }^{2}$. Estes sujeitos organizaram-se em grupos no Laboratório de Informática da referida escola para desenvolver Projetos de Ensino-Aprendizagem, tendo como ferramenta principal para a realização destas pesquisas as Tecnologias Digitais de Rede. Neste cenário, foi realizado um total de 23 encontros durante o processo de pesquisa empírica, a qual foi iniciada no mês de maio/09 e finalizada no mês de julho/09. Cada um destes encontros de pesquisa teve a duração de 3 horas e 30 minutos, sendo que o início ocorria às $13 \mathrm{~h}$ e $30 \mathrm{~min}$ e o fim às $17 \mathrm{~h}$, nas segundas, terças e sextas-feiras de cada semana.

Metodologicamente, a investigação empírica realizada pode ser classificada com o uma pesquisa qualitativa (BODGAN; BIKLEN, 1994) e, de uma maneira mais específica, com base na classificação por seus objetivos gerais (quanto aos fins da investigação), como uma pesquisa exploratória. (GIL, 2002). Com base nesta definição, foram selecionados alguns instrumentos de coleta de dados para a pesquisa empírica, sendo eles a observação participante, a entrevista semiestruturada e a análise de documentos. (LÜDKE; ANDRÉ, 1986). Quanto à escolha metodológica, com base nos procedimentos técnicos adotados, optou-se pelo estudo de tipo etnográfico. Este tipo de pesquisa, segundo André (2004, p. 2627), é uma adaptação da etnografia originalmente desenvolvida e utilizada pelos antropólogos

$2 \quad$ O estudo descrito neste artigo foi submetido por meio de projeto de pesquisa ao Comitê de Ética em Pesquisa, órgão ligado à Vice-Reitoria de Pesquisa e Pós-graduação da Universidade de Passo Fundo (UPF). O referido projeto foi devidamente aprovado e registrado, sob a seguinte numeração: CEP 035/2009, CAAE n. ${ }^{\circ}$ 0655.0.000.398-09. 
visando ao estudo da sociedade e da cultura. De modo geral, pode-se dizer que o processo de análise foi organizado em três momentos principais: (a) pré-análise, (b) exploração do material obtido, e (c) tratamento dos resultados obtidos e interpretação. (GOMES, 1994, p. 76).

\section{Análise dos Dados e Discussão dos Resultados}

A análise dos dados pautou-se por uma categoria norteadora, a "Ressignificação dos papéis de alunos e professores na ação educativa de desenvolvimento de Projetos de EnsinoAprendizagem (PEA), pela incorporação das características das Tecnologias Digitais de Rede (TDRs)”. Primeiramente, é importante ressaltar que, mesmo antes de ser iniciado o uso efetivo das tecnologias no processo de ensino-aprendizagem via projetos, o processo educativo ocorreu de maneira que, tanto os discentes quanto o docente (neste caso representado, em grande parte, pela figura do Pesquisador ${ }^{3}$ ), efetivaram as suas ações com base nas características advindas, principalmente, da lógica das redes e da interatividade.

Foi solicitado aos alunos, em um primeiro momento, que pensassem em questões e problemas que gostariam de pesquisar, que recordassem alguma dúvida ou indagação que os inquietassem e, sobre a qual, nunca tiveram a oportunidade de pesquisar, seja na escola ou fora dela. No que tange a esta atividade, a maioria dos alunos não apresentou nenhuma dificuldade para levantar uma série de problemas, temas e dúvidas que a eles interessavam. Muitos chegaram a levantar mais do que cinco questões/problemas, e um fato que surpreendeu muito neste contexto foi a diversidade das temáticas, o que ratifica a ideia de que os alunos são seres sociais que têm um percurso de interação com a cultura que diferem entre si, fato que reflete em suas motivações para o processo de ensino-aprendizagem.

Ou seja, a rede de ensino-aprendizagem que começa a se estabelecer no início dos PEAs já possui a característica hipertextual de ser heterogênea em sua composição, pois o que está em jogo neste contexto são os interesses e motivações diferenciados dos alunos, os quais, ao trabalharem em grupos de pesquisa, metamorfoseiam uma estrutura reticular de ensinoaprendizagem coletiva, negociando os processos que ocorreram no seu interior. (LÉVY, 1993,

3 Com o objetivo de manter o sigilo das informações, bem como a privacidade dos sujeitos pesquisados, a referência aos alunos ou professores participantes das atividades será efetivada com base no uso de nomes fictícios. Destaca-se, ainda, que a figura do sujeito que conduziu os processos de pesquisa junto à escola em questão será designada pelo termo "Pesquisador". 
p. 25-26; SERPA, 2004, p. 173).

Outro fato interessante foi a profundidade das questões levantadas, ou seja, assuntos que muitas pessoas assumiriam como complexos demais para crianças, mas que foram bastante recorrentes. A título de exemplo, a discente Maria formulou indagações tais como: Porque o mundo fica girando? Porque a água é azul quando a gente pega na mão ela é transparente? Por que as pessoas antigamente eram macacos? Porque a gente foi mudando de macaco para homem? A análise, neste caso em específico, pode referir-se primeiramente ao pressuposto de considerar o aluno um ser capaz de delimitar perguntas, de questionar sobre assuntos e temas que podem ser referenciados no processo educativo.

Considera-se assim o aluno como um nó efetivo da rede e que, por sua atitude protagonista, reconfigura a malha reticular, sendo também modificado durante este processo. (TEIXEIRA, 2010, p. 24). Este levar em consideração o aluno nas suas motivações e interesses, bem como considerar o discente como nó ativo da rede de ensino-aprendizagem que se estabelece, capaz de propor, opinar e refletir, pode ser constatado na fala de diversos discentes:

\footnotetext{
Alhan: [...] aqui a gente criou coisas né, a gente fez pesquisa, trabalho em grupo, a gente foi atrás das coisas e não ficamos apenas esperando a professora... A pesquisa é bastante diferente também...
}

Por meio do diálogo com os grupos de alunos, momentos onde o Pesquisador atuou, com as suas falas e intervenções, como um mediador do processo de ensino-aprendizagem, foi possível efetivar processos cognitivos conjuntos. (SILVA; CLARO, 2007, p. 83). Estas reflexões, por sua vez, foram materializadas na forma de sínteses textuais desenvolvidas pelos discentes, que descreviam as progressões, involuções, dúvidas e acertos que os alunos produziam à medida que suas pesquisas avançavam.

A observação da necessidade por diálogos mais sistemáticos entre Pesquisador e alunos na (re)definição das redes de conceitos espontâneos e científicos deu-se pelo seguinte fato: no desenvolvimento dos PEAs, a delimitação e ressignificação destas redes ocorriam por intermédio de respostas simples e pouco aprofundadas sobre as problemáticas iniciais da pesquisa. Em alguns casos, ocorreram respostas do tipo "sim ou não”, e em outros os alunos dissertavam minimamente sobre os problemas levantados, o que demandou uma intervenção do Pesquisador. Evidencia-se, assim, o caráter da intervenção pedagógica como propulsora dos processos de ensino-aprendizagem baseados no caráter interativo da ação educativa entre 
professor e alunos, onde o docente, em sua atuação mediadora, oportuniza momentos de cooperação, de atuação coletiva e cocriação das redes de conceitos científicos que vão sendo gradualmente internalizadas pelo discente. (SILVA, 2001, p. 5; VIGOTSKI, 1998).

Este processo coletivo de apropriação dos conhecimentos necessários à resolução de um PEA, inicialmente pelas discussões, debates e diálogos entre alunos e Pesquisador, é referenciado nas entrevistas dos alunos como o fator que movimentou o processo de ensinoaprendizagem dos conceitos a serem adquiridos para a resolução dos problemas e indagações de pesquisa:

Carmen: Ali no laboratório a gente fazia planejamento, pesquisava, ia atrás das coisas, participava mais do que na sala de aula... por exemplo, quando a gente faz pesquisa na sala de aula né, a gente não discute as coisas, pra ver o que cada um acha e tal, e também não conversa pra ver o que as pessoas quiseram dizer nas coisas que elas escreveram, e ali sim... a gente participa mais das coisas...

Pode-se notar ainda nas falas dos alunos o caráter não homogêneo desta intervenção pedagógica, visto que, como as demandas emanadas dos PEAs diferenciam-se uma das outras, este processo de diálogo, de ajuda e de negociação com os grupos de alunos necessitaram de uma postura tipicamente não linear das redes de ensino-aprendizagem que se estabelecem neste contexto:

Pesquisador: Porque tu achaste que foi mais fácil aprender aqui do que na sala de aula?

Milena: Porque lá a professora tem que ficar explicando pra 30 alunos, e ali não... ali todo mundo pesquisou o que queria... então assim, o senhor não ajudou todo mundo igual, ajudou um grupo, ajudou outro, de maneiras diferentes, e coisas diferentes... então não é nada comparado com isso...

Partindo dos pressupostos da interatividade, pode-se afirmar que a materialidade da ação educativa ocorreu, neste contexto, fundada nas concepções de efetivar os processos de ensino-aprendizagem por meio da bidirecionalidade da comunicação e do diálogo, da participação-intervenção de todos os envolvidos na rede de ensino-aprendizagem que se instaura. (SILVA, 2001, p. 5). Consequentemente criam-se novas possibilidades de efetivação do processo de ensino-aprendizagem via PEAs por caminhos ainda não pensados pelos discentes. (SILVA, 2002, p. 73). Nestes termos, do mesmo modo como os alunos assumiram a centralidade dos processos que se instauram na rede de ensino-aprendizagem, em diversos casos a necessidade da mobilidade do centro para a figura do professor se faz necessária para 
que haja uma abertura de novas potencialidades para o processo educativo. (LÉVY, 1993, p. 25-26; SERPA, 2004, p. 173).

Neste contexto, outras atividades foram executadas pelos alunos, como a elaboração sistemática de um documento, escrito colaborativamente, denominado de Planejamento Geral. Este documento tinha por objetivo ser um meio para a gerência e organização das atividades a serem desenvolvidas na execução de um PEA, oportunizando aos alunos uma importante ferramenta para pensarem de maneira planificada. Um exemplo de como a atividade de planejar em conjunto oportunizou aos alunos momentos de protagonismo e ao Pesquisador momentos de intervenção pedagógica baseada no diálogo e na negociação, refere-se a um acontecimento no grupo de pesquisa dos discentes José e Caroline. Um destes discentes (José) expressou em determinado momento de efetivação do Planejamento Geral que estava interessado em levantar mais questões sobre os dinossauros e procurar informações adicionais sobre o assunto e, para que isto ocorresse, ele começaria a frequentar a escola em horários alternativos, realizando algumas pesquisas na biblioteca e nos computadores.

Deste processo, desencadeou-se uma intervenção do Pesquisador para que fosse refletida a planificação que encaminhasse uma demanda neste sentido, pois, apesar da mobilização expressada pelos alunos, a definição formal de execução futura de uma atividade produtiva para o PEA em questão não havia sido realizada. Notou-se que os alunos também estavam tomando para a si a responsabilidade de realização das atividades que levam ao desenvolvimento dos seus PEAs, seja levantando demandas, vislumbrando possibilidades, discutindo problemáticas, redes de conceitos espontâneos e científicos com o Pesquisador, ou demonstrando intenções de efetivar processos de pesquisa, de busca por informações de maneira autônoma.

Este contexto de reflexões pode ser encontrado nas falas dos alunos que participaram do processo investigatório:

Pesquisador: O que você fez ali no laboratório, durante as pesquisas, que na sala de aula tu não faz ou não pode fazer geralmente [...]?

Carmen: [...] não podemos mexer no computador, porque não tem como, lá não tem... pesquisa também não fizemos, trabalhar em grupo... a gente não fazia aquelas coisas de planejar também o que a gente ia fazer num dia, $e$ nos outros... pesquisar coisas do nosso interesse... na sala de aula a gente faz pesquisa, mas daí a gente responde com o que a gente que, e daí a sora corrige e fala se ta errado ou certo...

O que é passível de se analisar é que, ao estabelecer equilíbrio entre a intervenção 
pedagógica exercida pelo Pesquisador e a consideração das motivações, conhecimentos e interesses que o aluno possui, consegue-se a efetivação de uma práxis pedagógica baseada na mediação pelo diálogo e a negociação entre professor e aluno. Neste contexto, ocorre uma ruptura tanto com a "lógica vertical e hierárquica” quanto com a "lógica do espontaneísmo", de onde emergem processos de negociação horizontais entre os sujeitos que se posicionam como nós ativos da rede de ensino-aprendizagem, fazendo com que a centralidade dos processos instaurados se configure conforme a lógica das redes e do hipertexto. (RAMAL, 2002, p. 206-227).

Vale relembrar que a ressignificação dos papéis e do relacionamento de professores e alunos por meio de conceitos como a interatividade, lógica das redes e hipertexto/hipermídia, perpassa pela seguinte reflexão: não é necessariamente a simples presença das TDRs em um ambiente educativo que fará com que os processos educativos ocorram de maneira a incorporar as características destas tecnologias. Observando estas colocações, pode-se dizer, porém, que a efetiva apropriação das TDRs no processo educativo via PEAs, por parte dos alunos, Pesquisador e demais seres sociais envolvidos na rede de ensino-aprendizagem, abre novas perspectivas para a efetivação da intervenção pedagógica e da retomada do protagonismo e da coautoria na redefinição dos papéis dos sujeitos envolvidos na ação educativa interativa.

Neste sentido, vale citar a atividade desenvolvida pelo Pesquisador e demais seres sociais fora do espaço-tempo escolar onde a pesquisa empírica realizou-se, onde, ao levantarem sistematicamente uma série de comentários nos textos coletivos construídos pelos alunos por meio da TDR Google Docs, oportunizaram momentos de ajuda e intervenção nas problematizações, colocando dúvidas adicionais, questionando sobre as novas sínteses desenvolvidas pelos discentes, propondo novos ângulos de análises acerca das redes de conceitos. Estas interações sociais, estabelecidas pelo Google Docs, configuraram um processo de ensino-aprendizagem onde se tornou possível o alargamento da comunicação interativa, de tal forma que não fossem simplesmente providas respostas prontas, análises já concluídas, mas sim um conjunto potencial de conceitos e sugestões a serem manipuladas, analisadas pelos alunos.

Alhan: Aqui a gente pesquisava quase sempre no computador, e lá em livro, caderno e mais outras coisas... E no computador a gente ia atrás das coisas pra pesquisa, entrava em contato com as pessoas, falava com elas, pedia explicação... Na sala de aula a professora dá as coisas da pesquisa e pede pra fazer as coisas que ela quer... 
Concluindo, o Pesquisador atuou em diversos papéis, garantindo a materialidade da ação interativa durante o processo educativo, ou seja: promovendo ajuda nas primeiras aproximações do aluno com as TDRs, explicando desde como funciona a interface gráfica destas, as atividades possíveis de serem efetuadas; cuidando para que, durante as interações sociais estabelecidas, as redes de conceitos científicos sejam progressivamente construídas pelos diálogos e negociações de caráter colaborativo que confluam para as internalizações a serem realizadas pelos alunos; ajudando na coordenação das atividades do grupo, cuidando para que todos os alunos vivenciem os momentos de ensino-aprendizagem disponibilizados por intermédio do processo de desenvolvimento de PEAs com a ajuda das TDRs. (RAMAL, 2002, p. 206-227).

Ainda neste contexto, outra atividade desenvolvida na investigação empírica, e que possibilitou reconhecer como o papel do aluno pode ser ressignificado em um ambiente educacional embasado nas ideias de utilização dos PEAs e das TDRs, foi a criação de um produto final da pesquisa (artefato) que deveria compilar todas as descobertas e conhecimentos internalizados durante os processos de ensino-aprendizagem, sugestão do José em um dos momentos de efetivação do Planejamento Geral da pesquisa do seu grupo. Nesta tarefa de planejamento, o aluno relatou que havia assistido, em sua casa, a um desenho animado sobre dinossauros, objeto de estudo da sua pesquisa, e que, em sua opinião, ao final de todo o processo de desenvolvimento do seu PEA, seria possível também fazer um filme.

Com base na fala deste discente, foi realizada posteriormente uma discussão com todos os alunos sobre a possível produção de um artefato final da pesquisa, a ser delimitado pelos grupos em conjunto com o Pesquisador. Nestes termos, todos os alunos concordaram com a proposta, sendo que foi decidida, ainda, esta atividade como a última tarefa do processo educativo emanado das pesquisas via PEAs com a apropriação das TDRs. Assim, cada grupo de alunos criou o seu produto final de pesquisa, utilizando os conhecimentos apropriados durante o desenvolvimento dos PEAs, sendo eles: a) uma maquete e um vídeo sobre a temática “dinossauros”"; b) um conjunto de slides sobre a temática "cobras”, produzidos com o Google Docs de maneira colaborativa ${ }^{5}$; c) um site dispondo as informações da pesquisa sobre a temática “céu e água” de maneira hipermidial.

Ao decidir pela adoção da ideia de um colega como possível atividade do processo de

\footnotetext{
$4 \quad$ Disponível no seguinte link: <http://www.youtube.com/watch?v=rjTGbq_6sTc>.

Para acessar este documento, utilize o link a seguir, solicitando compartilhamento do mesmo: <http://docs.google.com/present/edit?id=0Abb-MpDEDe8jZGc0dHA2cmZfMG02dHRwM2Ni\&hl=pt_BR>.
} 
ensino-aprendizagem via PEA, os alunos mostraram que o protagonismo que se estabelece neste contexto, característico dos processos de ensino-aprendizagem baseados na lógica das redes e na interatividade, está diretamente conectado com a questão de saber refletir acerca de sugestões, bem como de opinar e discutir possíveis caminhos a serem seguidos. Logo, é possível observar que: a) os rumos dos processos educativos nas redes de ensinoaprendizagem que derivaram do desenvolvimento de cada PEAs foram diretamente influenciados pela sugestão dos próprios alunos; b) que somente considerando estes discentes como sujeitos ativos e, portanto, capazes de propor e de analisar ideias, torna-se possível potencializar um ambiente educacional embasado na apropriação dos PEAs imbricados com as TDRs.

\footnotetext{
Alhan: Gostei de tudo, mas com relação a tudo foi... os slides...

Pesquisador: Uhum, fazer o produto final da pesquisa... E porque tu gostou mais de fazer isso?

Alhan: Eu gostei porque daí a gente foi lá e aprendemos a fazer slides, botamos fotos, escrevemos nos slides as coisas que a gente tinha aprendido na pesquisa... botar os vídeos, os montes de fotos...
}

Ainda, outra análise relevante sobre as potencialidades que a produção do artefato possibilitou, para que os alunos fossem protagonistas de suas aprendizagens, foi a demanda que este processo criou para que novas interações sociais e processos de ensino-aprendizagem fossem delimitados. Isso ficou bastante claro na fala do José, ao iniciar o desenvolvimento da síntese final das redes de conceitos científicos contidas em seu PEA, conjuntamente com a sua colega de grupo Caroline, visando à realização do desenvolvimento do produto final da pesquisa.

Este discente relatou que seria necessário aprender mais sobre algumas questões e indagações-guia que ainda não estavam completamente solucionadas, bem como que seria necessário buscar informações que ainda não faziam parte do seu PEA, mas que seriam essenciais para o desenvolvimento do artefato final de pesquisa. Neste sentido, percebe-se que a delimitação de um produto final da pesquisa foi extremamente positiva para a abertura de novas demandas de pesquisa, potencializando a realização de processos de ensinoaprendizagem entre alunos, Pesquisador e demais sujeitos envolvidos na rede de ensinoaprendizagem do PEA em questão.

Concluindo, o desenvolvimento dos processos de ensino-aprendizagem foi ocorrendo por meio da ressignificação do papel de professor e alunos, mediante a noção de que estes dois sujeitos agiram de maneira que estes processos ocorreram, de fato, por meio da 
participação efetiva de todos os envolvidos no contexto educativo emanado da utilização dos PEAs em conjunto com as TDRs.

\section{Conclusões}

Com base no diálogo interdisciplinar fecundo, baseado em estudos nas áreas da Informática e da Educação, tornou-se possível desvelar conceitos, metáforas e reflexões advindas do âmbito sociotécnico da cibercultura, tais como a lógica das redes, o hipertexto/hipermídia, a interatividade e a inteligência coletiva, os quais propiciam um meio de potencialização da proposta pedagógica de uso dos PEAs. Nesse contexto, a imbricação entre PEAs e TDRs postula a necessidade de processos de ensino-aprendizagem colaborativos, onde se operam modificação da relação e dos papéis de alunos e professores, e, ainda, da organização e da estrutura curricular.

Por meio deste esforço intelectual foi possível atingir os objetivos da pesquisa no que tange, principalmente, às reflexões teóricas que nortearam o trabalho interdisciplinar. Porém, este processo propiciou, ainda, um conjunto de conceitos e categorias que embasassem a execução de uma investigação empírica estreitamente conectada com o referencial teórico desenvolvido. Desse modo, com o intuito de analisar um conjunto de dados advindos de uma experiência prática de utilização dos PEAs por um grupo de alunos, os quais se apropriaram de TDRs para a efetivação dos processos de ensino-aprendizagem, delimitou-se uma pesquisa do tipo etnográfica na Escola Estadual de Ensino Fundamental Capistrano de Abreu, Soledade-RS.

Com base nesta pesquisa empírica, tornou-se viável analisar as dinâmicas que surgem quando da apropriação das características das TDRs para a potencialização de processos educativos baseados nos PEAs. Por meio do processo investigatório conseguiu-se atingir níveis mais elevados de compreensão da importância da ressignificação dos papéis de alunos e professores, quando estes atuam em um ambiente educativo conectado a ideia da lógica das redes e da interatividade advinda das TDRs. Foi possível verificar que, no desenvolvimento de PEAs, assumir-se como um nó da rede de ensino-aprendizagem que se estabelece é essencial para que os alunos efetivem, conjuntamente com o professor, processos educativos que ocorram na perspectiva da participação-intervenção. Porém, foi possível analisar que, se o professor não deve atuar meramente como um transmissor de conhecimentos, ele também não deve abster-se completamente do processo educativo, baseando sua intervenção pedagógica 
na premissa do espontaneísmo, onde o aluno opera como "guia" da ação pedagógica.

Nestes termos, o que se verificou é que a ressignificação dos papéis de alunos e professores pressupõem compreender os processos de ensino-aprendizagem como atos comunicativos baseados na ideia de diálogos bidirecionais-híbridos, onde tanto alunos como professores podem emitir e receber informações. Por intermédio da realização conjunta de processos cognitivos intersubjetivos de análise e de síntese, torna-se possível estabelecer interações sociais mediatizadas pelas TDRs e que concorram para que os alunos efetivem a internalização dos conceitos científicos envolvidos no desenvolvimento dos seus PEAs.

A apropriação das TDRs nas atividades realizadas abriu possibilidades para que ocorresse uma expansão do potencial comunicativo entre alunos e professores, e ainda com demais seres sociais localizados em espaços-tempos virtuais. Os alunos, ao se apropriarem das possibilidades inerentes ao estabelecimento de processos de interação social no ciberespaço, encontraram nas TDRs uma forma para expandir a sua teia de relações visando ao ensino-aprendizagem, de uma maneira que não seria possível sem a presença destas tecnologias. Portanto, as atividades educativas desenvolvidas na pesquisa empírica permitiram uma reflexão sobre as TDRs enquanto articuladoras da efetivação de processos de ensino-aprendizagem potenciais no ciberespaço, por meio do contato com ideias, teorias, pessoas, instituições, enfim, possíveis nós a serem integrados à rede de ensino-aprendizagem.

Em suma, a participação necessária de todos os envolvidos na rede de ensinoaprendizagem, o estabelecimento de processos cognitivos intersubjetivos entre os envolvidos na ação educativa e a consequente colaboração como traço fundamental do ato de conhecimento, demonstraram que uma apropriação efetiva das potencialidades das TDRs passa pela opção por um sistema didático que tenha sinergia com a aplicação educacional destas tecnologias. Nestes termos, o desenvolvimento de PEAs demonstrou ser um meio para efetivar os processos de ensino-aprendizagem sob a égide das características das TDRs, as quais propiciam, principalmente, processos de ensino-aprendizagem baseados na perspectiva da autoria colaborativa de conhecimentos.

\section{Referências}

ANDRÉ, Marli Eliza Dalmazo Afonso de. Etnografia da prática escolar. 11. ed. São Paulo: Papirus, 2004.

BARBOSA, Maria Carmem Silveira. Trabalhando com projetos na educação infantil. In: DALLA ZEN, Maria Isabel H; XAVIER, Maria Luisa M. (Org.). Planejamento em destaque: 
análises menos convencionais. 2. ed. Porto Alegre: Mediação, 2000 (pp. 75-96).

BODGAN, Roberto C.; BIKLEN, Sari K. Investigação qualitativa em educação: uma introdução à teoria dos métodos. Portugal: Porto Editora, 1994.

DEWEY, John. Democracia e educação: introdução à filosofia da educação. 3. ed. São Paulo: Nacional, 1959.

FAGUNDES, Léa da Cruz; SATO, Luciane Sayuri; MAÇADA, Débora Laurino. Aprendizes do futuro: as inovações começaram! Coleção Informática para a mudança na Educação. Brasília: MEC/SEED/ProInfo, 1999.

GIL, Antonio Carlos. Como elaborar projetos de pesquisa. 4. ed. São Paulo: Atlas, 2002.

GOMES, Romeu. A análise de dados em pesquisa qualitativa. In: MINAYO, Maria Cecília de Souza (Org.). Pesquisa social: teoria, método e criatividade. 23. ed. Petrópolis: Vozes, 1994 (pp. 67-80).

HERNÁNDEZ, Fernando. Transgressão e mudança na educação: os projetos de trabalho. Porto Alegre: ArtMed, 1998.

KILPATRICK, William Heard. The project method. Teachers College Record, Nova York, v. 19, n. 4, 1918 (pp. 319-335).

LEMOS, André. Cibercultura: alguns pontos para compreender a nossa época. In: LEMOS, André; CUNHA, Paulo (Org.). Olhares sobre a cibercultura. Porto Alegre: Sulina, 2003 (pp. 11-23).

LÉVY, Pierre. A inteligência coletiva: por uma antropologia do ciberespaço. 4. ed. São Paulo: Loyola, 2003.

. As tecnologias da inteligência: o futuro do pensamento na era da informática. Rio de Janeiro: Editora 34, 1993.

. Cibercultura. São Paulo: Editora 34, 1999.

Caderno 5, p. 3.

. O digital e a inteligência coletiva. Folha de São Paulo, São Paulo, 06 jul. 1997.

LOURENÇO FILHO, Manuel B. Introdução ao estudo da escola nova: bases, sistemas e diretrizes da pedagogia contemporânea. 12. ed. São Paulo: Melhoramentos, 1978.

LÜDKE, Menga; ANDRÉ, Marli Eliza D. A. de. Pesquisa em educação: abordagens qualitativas. São Paulo: EPU, 1986.

OLIVEIRA, Marta K. de. Vygotsky, aprendizado e desenvolvimento: um processo sóciohistórico. São Paulo: Scipione, 1997.

RAMAL, Andrea Cecília. Educação na cibercultura: hipertextualidade, leitura, escrita e aprendizagem. Porto Alegre: ARTMED, 2002. 
SANTAELLA, Lúcia. Navegar no ciberespaço: o perfil cognitivo do leitor imersivo. São Paulo: Paulus, 2004.

SERPA, Felippe. Rascunho digital: diálogos com Felippe Serpa. Salvador: Edufba, 2004.

SILVA, Marco; CLARO, Tatiana; A docência online e a pedagogia da transmissão. Boletim Técnico do Senac, São Paulo, v. 33, n.2, maio/ago. 2007. Disponível em:

<http://www.senac.br/BTS/332/artigo-7.pdf>. Acesso em: 21 out. 2008.

SILVA, Marco. Interatividade: uma mudança fundamental do esquema clássico da comunicação. Boletim Técnico do SENAC, São Paulo, v. 26, n. 3, set./dez. 2000. Disponível em: <http://www.senac.br/BTS/263/boltec263c.htm>. Acessado em: 12 set. 2008.

. O que é interatividade. Boletim Técnico do SENAC, São Paulo, v. 24, n. 2, maio/ago. 1998. Disponível em: <http://www.senac.br/BTS/242/boltec242d.htm>. Acesso em: 21 jan. 2009.

. Sala de aula interativa. 3. ed. Rio de Janeiro: Quartet, 2002.

. Sala de aula interativa: a educação presencial e a distância em sintonia com a era digital e com a cidadania. Boletim Técnico do SENAC, São Paulo, v. 27, n. 2, maio/ago. 2001. Disponível em: <http://www.senac.br/BTS/272/boltec272e.htm>. Acesso em: 19 nov. 2008.

SNYDERS, Georges. Pedagogia Progressista. Coimbra: Livraria Almedina, 1974.

TEIXEIRA, Adriano Canabarro. Inclusão digital: Novas perspectivas para a informática educativa. 1. ed. Ijuí/RS: Edutora Unijuí, 2010.

VIGOTSKI, Lev S. A formação social da mente: o desenvolvimento dos processos psicológicos superiores. 6. ed. São Paulo: Martins Fontes, 1998.

. Pensamento e linguagem. 3. ed. São Paulo: Martins Fontes, 1991.

Recebido em: maio de 2012

Aprovado em: setembro de 2012 